\title{
Da Frankrig brændte
}

\section{Connie Pedersen}

\section{Efteråret 2005 blev varmt i Frankrig. I ghettofor- stæderne til Paris og de store provinsbyer gjorde unge anden-og tredjegenerationsindvandrere op- rør. De er desperate og føler sig lukket ude af det franske samfund}

I tre uger oplyste orange flammer fra biler i eksplosionsagtig brand nattehimmelen i forstæderne til $\mathrm{Pa}$ ris og andre store byer. De sodsværtede rester af skoler og forretninger vidner om optøjer, som Frankrig ikke har oplevet magen til i moderne tid. En hårdt presset regering $o g$ en svag præsident svarede tilbage med udgangsforbud og med en social hjælpepakke til de fattige forstæder. EU trådte også til med millioner af euro.

Præsident Jacques Chirac analyserede krisen sådan her, da han efter næsten tre ugers optøjer talte til nationen på TV: "Dette er en krise, der handler om retning, en krise, der drejer sig om holdepunkter, en identitetskrise".

Juridisk er der ikke tvivl om de unge uromageres identitet. De er stort set alle franske statsborgere, men deres bedsteforældre eller for- ældre er indvandrere. De unge hader ordet integration, for de betragter ikke sig selv som fremmede, der skal integreres i Frankrig. Men de opfører sig ikke som en del af det franske samfund med dets traditioner, regler og love, og det franske samfund behandler heller ikke dem ikke som en del af fællesskabet.

Efter en uge i Paris under optøjerne har jeg en klar fornemmelse af, at forstædernes beboere føler sig udelukket af det franske samfund. De unge føler ikke, at de har samme fremtidsudsigter som unge i resten af Frankrig. De har oplevet deres forældre hutle sig igennem, og sådan vil de ikke have det. De vil ikke bare overleve, men leve. De er trætte af at hænge i en trist opgang med neon-belysning og ryge hash, mens unge inde i Paris kan gå på diskotek i lækkert tøj og købe dyre drinks. De drømmer om at få et arbejde, et 
hjem og en velfungerende familie. Men det er gået op for dem, at det får de nok ikke, for de har ikke udsigt til nogen ordentlig løn. Mange er droppet ud af skolen, de har ingen faglig uddannelse og ikke noget arbejde, og de orker ikke at gøre noget ved deres situation. I desperation griber de en molotovcocktail og smider den ind i naboens bil eller ind på den forhadte skole.

\section{Begivenheden}

Det begyndte den 27. oktober i Paris-forstaden Clichy-sous-Bois. Tre unge, der med rette eller urette tror, de bliver forfulgt af politiet, klatrer over muren til en transformatorstation. To af dem bliver dræbt af elektrisk stød, og den tredje bliver svært forbrændt.

Det er dagligdag, at politiet går hårdt til værks over for de unge $i$ forstæderne. De forlanger at se deres ID-kort sommetider flere gange om dagen, og det er en ydmygelse, siger de unge igen og igen. De bliver tit anholdt og tilbringer timer på politistationen. Men politiet har heller ikke nogen let opgave i ghettoforstæderne, der er plaget af kriminalitet. Der er områder, hvor politiet nødigt kommer, fordi det er for farligt.

Så det var lang tids frustration, der fik luft, da de unge i Clichy-sousBois begyndte at satte ild til biler og skraldespande efter de to unge mænds død. Det bredte sig til andre parisiske forstæder og til provinsbyer andre steder i Frankrig, fx omkring Strasbourg, Toulouse og Lyon. Først efter næsten tre uger klingede urolighederne af, og regeringen fik kontrol med situationen. Men problemerne i forstæderne er lige så store, som de hele tiden har været.

Der er omkring 800 såkaldte udsatte eller hårdt belastede forstæder i Frankrig, og der bor ca. fire mio. mennesker i dem - de fleste med indvandrerbaggrund.

De bor i de såkaldte "citès". Det er høje, massive boligblokke, der lukker sig om sig selv som ghettoer. Det kan $\mathrm{fx}$ være en ti-etagers blok med 250 lejligheder og ca. 1000 indbyggere. De kan også være endnu større. Her er familierne presset sammen i dårlige lejligheder, kriminalitet og narkohandel er udbredt, arbejdsløsheden er meget højere end i resten af Frankrig, og skolesystemet har givet op. Kort sagt integrationen er slået fejl. Rundt om "les cités" kan der godt være almindelige parcelhuse, grønne områder, butikker, børnehaver og skoler, der fungerer.

\section{Historien}

Ideen med de store sociale boligbyggerier i industriforstæderne var god nok, da den blev lanceret i 1950'erne. Dengang var boligforholdene for folk med små indtægter usle, og der fandtes egentlige slumkvarterer rundt om Paris. Så de nye højhuse med rindende vand og ordentlige 
toiletforhold var et stort fremskridt. Franske arbejderfamilier i stort tal flyttede ind, og de var glade og stolte over deres nye hjem. Mellem 1950 og 1960 blev der bygget 270.000 sociale boliger.

Men i løbet af 1960'erne og 70'erne ændrede beboersammensætningen sig. Alene fra Algeriet kom der en mio. mennesker til Frankrig, efter at Algeriet var blevet selvstændigt i 1962, og de skulle have et sted at bo i en fart. Det blev det sociale boligbyggeri.

I 1970'erne hentede især bilindustrien tusindvis af immigranter ofte dårligt uddannede - til landet. Alene i $1970 \mathrm{kom}$ der 300.000. De flyttede også ind i de høje boligblokke uden for Paris og andre storbyer. Til gengæld flyttede de oprindelige beboere - de franske arbejderfamilier - væk, så snart de kunne få råd til det, og langsomt begyndte forfaldet.

Borgerlige og socialistiske regeringer har på skift forsøgt at finde en løsning på problemet. I øjeblikket er planen at rive ned, modernisere og bygge nyt. I 1986 blev der lagt dynamit under det første boligtårn, og i en sky af sten og støv lagde det sig ned på siden.

\section{Arbejdsløshed}

Men boligen er kun den ydre ramme om de sociale problemer, der plager Frankrig. De to alvorligste er arbejdsløsheden og skolesystemets fallit. De fører direkte frem til dårlig integration og udstødelse. Arbejdsløsheden er en svøbe, der rammer både unge og gamle - både forældregenerationen og deres børn og den ødelægger forholdet mellem dem. Som en far sagde, da han blev bebrejdet, at han ikke tog hånd om sin søn: "Jeg vil gerne i dialog med min søn, men han respekterer mig ikke, for jeg har været arbejdsløs i fem år."

Den franske økonomi har det skidt, og arbejdsløsheden for hele landet er høj målt med europæisk målestok nemlig ca. 10 pct. Men i ghettoforstæderne er den ca. 20 pct., og ungdomsarbejdsløsheden er over 30 pct.

Bedsteforældregenerationen har prøvet at have et arbejde. De kom til Frankrig i løbet af de "gyldne 30 år" efter Den Anden Verdenskrig. Dengang var den franske økonomi i en rivende udvikling, og der var brug for arbejdskraft i miner, industri og byggeri.

Men da anden generation af indvandrere skulle ud på arbejdsmarkedet, var Frankrig blevet ramt af den verdensøkonomiske krise, som fulgte oliekrisen midt i 1970'erne. Den generation snublede i starten, og mange fandt aldrig rigtig fodfæste på arbejdsmarkedet. Deres ulykke er, at den slags jobs, hvor man først og fremmest skal bruge sine hænder, bliver der færre og færre af. Der er forsvundet over en million arbejdspladser i industrien i de sidste 30 år. Dem, der er blevet afskediget, 
er ikke blevet omskolet til nye job, men har affundet sig med tingenes tilstand.

Det er anderledes med den tredje generation - de unge - og dem er der rigtig mange af i forstæderne. I Clichy-sous-Bois, hvor det hele begyndte, er ca. halvdelen af indbyggerne under 25 år, og en ud af tre er uden arbejde. Generelt er der en ungdomsarbejdsløshed på omkring 36 pct. i forstæderne, og den har været stigende de sidste 15 år. Bistandshjælp gives kun til unge over 25 år.

De unge i ghettoforstæderne er for dårligt uddannede, og så er de også udsat for diskrimination. Hvis man hedder Abdel eller Fatima, skal man regne med at skrive 8-10 gange så mange jobansøgninger, som hvis man hed Pierre eller Maryse, og det er vel at mærke unge, der har lige gode eksamenspapirer. Det rammer især drengene.

Det får nogle af de unge til at tænke: Jeg får hurtigere mine designerjeans, min Lacoste-sweater og den nyeste mobiltelefon ved kriminalitet - tyveri og narkohandel - end ved at passe min skole og bagefter gå og vente på et arbejde. Fællesskabet finder de i bander, som får kontrollen over et kvarter og lægger et stort pres på andre i opgangen for at være med.

Der blev anholdt 3000 unge under optøjerne, og der har været en diskussion, om hvorvidt det især var kriminelle, der deltog i optøjerne. Indenrigsminister Nicolas Sarkozy var hurtigt ude og sige, at 80 pct. af de anholdte var unge, som politiet allerede kendte. Men det ser ud til at være forskelligt fra by til by. Nogle steder var de kriminelle uromagere klart i mindretal, andre steder var det dem, der førte an på gaderne om natten.

Det ser ikke ud til, at religionen har spillet nogen særlig rolle i urolighederne. De unge uromagere har deres kulturelle rødder i islam, men troen er ikke vigtig for dem.

Et par dage efter at urolighederne var brudt ud, udstedte en rabiat islamisk organisation en fatwa mod urolighederne, men det fik overhovedet ingen virkning. De unge uromagere retter sig ikke efter nogen autoritet, heller ikke en religiøs. De er ikke specielt politisk bevidste eller særlig velformulerede, men de har en stor vrede i sig, og det var den, der satte biler i brand, når natten faldt på. Det gik også ud over skoler i flere forstæder. For mange af de unge er skolen symbolet på deres første nederlag i det franske samfund.

\section{Skolen}

Skolen spiller en stor rolle i det franske samfund, måske fordi den har været en politisk kampplads i meget højere grad end fx i Danmark. I over 100 år kæmpede den katolske kirke og den verdslige stat om kontrollen over skolen, og det blev staten, der vandt. Det er en vigtig opgave for skolen at være en so- 
cial elevator, der skal transportere et ungt menneske opad i samfundet. Men elevatoren kører ikke i de høje boligblokke i forstæderne. En af de unge udtrykte det sådan her over for en avis: "Den sociale elevator er gået i stykker, så jeg tager trappen". I hans tilfælde betød det, at han klarede sig ved kriminalitet.

Statistikken taler sit tydelige sprog: Børnene fra ghettoforstæderne forsømmer mere end børnene andre steder. De dumper hyppigere. Færre fuldfører en skoleuddannelse. Der har ikke i de seneste 15 år været så få arbejderbørn på de højere læreanstalter, som der er i dag.

Forklaringerne er flere: Børnene i ghettoforstæderne har et dårligt udgangspunkt, fordi de kommer fra ikke-boglige, ofte hårdt belastede miljøer. Skoleklasserne er overfyldte, og lærerne er meget unge og uerfarne. I de udsatte forstæder uden for Paris er omkring en tredjedel af lærerne under 30 år. De ældre, mere erfarne lærere styrer deres karriere uden om skolerne med landets vanskeligste og somme tider voldelige elever.

Der er gjort forsøg på at rette op på skæwhederne. For næsten 25 år siden blev der gennemført et system med "højtprioriterede uddannelseszoner". Det gik ud på at give flere penge til uddannelse i de områder, der har mindst og gøre en ekstra pædagogisk indsats der. Men resultaterne har været omdiskuteret. En kritisk rapport fra sidste år kom til den konklusion, at systemer med de særlige zoner ikke har haft nogen positiv virkning på elevernes resultater.

Præsident Chirac brugte i sin tvtale den 14. november den vending, at "alle børn er republikkens børn". En parisisk taxa-chauffør med indvandrerbaggrund omskrev det over for mig til, at alle børn er blomster, men det afhænger af den jord, de kommer til at vokse i, om de bliver smukke eller ej.

\section{Undtagelsesloven}

Det har ulmet længe i ghettoforstæderne. Alligevel overrumplede optøjerne de franske myndigheder. Politiet med skjolde og tåregas og brandfolk med slanger og skumslukkere kom til kort over for de unge. Som nætterne gik, meldte kravet sig om en mere effektiv indsats. Det kom fra folk i forstæderne, som fik deres dyrt købte - og måske ikke forsikrede - bil brændt af. Det kom fra franskmænd, der frygtede, at urolighederne ville brede sig til deres fredelige boligkvarter. Det kom fra borgmestre af alle partifarver og særlig markant fra borgerlige politikere. Nogle højrefløjspolitikere krævede militæret sat ind.

En meningsmåling i avisen $\mathrm{La} \mathrm{Li}$ bération viste, at 71 pct. af de adspurgte var utilfreds med regeringens håndtering af urolighederne $\mathrm{i}$ de første par uger.

Så den 7. november gav premier- 
minister Dominique de Villepin et interview til fransk tv og erklærede at der skulle findes "en fast og retfærdig løsning”. Samme dag døde en ældre mand, som var blevet slået ned af en af de unge uromagere. Det faste i regeringens politik bestod $i$, at den vakte en 50 år gammel lov om undtagelsestilstand til live og satte 1500 ekstra politifolk ind. Det retfærdige var en række sociale hjælpeforanstaltninger - mere om dem senere.

Det er en lov fra 1955, regeringen har pustet nyt livi. Den blev gennemført i den turbulente tid, da Algeriet kæmpede for sin uafhængighed, og den er ikke blevet brugt siden i Frankrig. Loven giver de lokale myndigheder mulighed for at gennemføre udgangsforbud, og det var, hvad Villepins regering havde bruge for. Da urolighederne var på det højeste, benyttede 32 byer sig af muligheden for at forbyde unge at være ude om natten.

Loven blev også brugt til at gennemføre et forbud mod demonstrationer og sammenstimlen i Paris i weekenden 11. til 13. november. Det var en lang weekend, fordi franskmændene holder fri på årsdagen for våbenstilstanden i Den første Verdenskrig den 11. november, og politiet frygtede, at de unge fra forstæderne ville bruge de tre fridage til at slå til inde midt i Paris. De sagde, de havde opsporet en livlig trafik på mobiltelefoner og internet om planlagte aktioner i den franske hoved- stad. Men de tre fridage forløb roligt, og urolighederne i forstæderne begyndte også at klinge af, og de døde helt ud den følgende uge.

En meningsmåling viste, at 73 pct. af franskmændene støttede udgangsforbudene. Men der var også kritik. I mange belastede forstæder, hvor der kun havde været få tilfælde af brændte biler, frygtede beboerne, at de ville blive sat under administration. Mange af dem kommer fra Algeriet, og det vakte dårlige minder, at de blev behandlet ligesom deres bedsteforældre.

Flere juridiske eksperter mente, at regeringen skød spurve med kanoner, for republikken var ikke i fare, sagde de. Nogle politiske kommentatorer fortolkede først og fremmest regeringens skridt som et signal til vælgerne om fasthed. Le Monde skrev i en leder, at premierministeren havde tabt hovedet og demonstreret, at han endnu ikke havde "en statsmands nerver".

Den socialistiske opposition i Nationalforsamlingen holdt en bemærkelsesværdig lav profil. Måske fordi den i virkeligheden var enig med regeringen, måske fordi den også kunne læse meningsmålingerne, og endelig fordi den netop i de dage havde travlt med et internt opgør.

Da undtagelsesloven efter en uges forløb skulle forlænges i tre måneder ved en afstemning i nationalforsamlingen, stemte socialisterne dog imod. 


\section{Social hjælpepakke}

Undtagelsesloven var den "faste" del af regeringens svar på urolighederne. Den "retfærdige" del bestod i en social hjælpepakke til forstæderne. Et element i den pakke var, at der skulle oprettes flere såkaldte økonomiske frizoner. Det er en udbygning af en meget vellykket ordning, der går ud på, at virksomheder, der vil slå sig ned i ghettoforstæderne, bliver fritaget for skat og sociale omkostninger i en årrække. Til gengæld skal en tredjedel af de ansatte komme fra de hårdt belastede forstæder.

Der fandtes 85 af den slags zoner før urolighederne, og i dem var der oprettet 15.000 nye virksomheder med 60.000 nye jobs. Det er en større succes, end man havde regnet med, da ordningen blev gennemført, og det bekræfter, at det ikke er flere overførselsindkomster til den enkelte, der er brug for, men økonomisk vækst og arbejdspladser. Problemet med ordningen er, at den er geografisk begrænset til de zoner, der bliver etableret. Derfor var regeringens udspil under urolighederne, at der skal oprettes nye frizoner -15 bliver det til. Den løsning er alle tilfreds med.

Derimod er der stor diskussion om et andet element i regeringens krisepakke, nemlig den del, der går ud på, at unge skal kunne forlade skolen, når de er 14 år i stedet for som nu 16 år. Tilhængerne af ord- ningen fremhæuer, at unge, der alligevel ikke passer deres skole og oplever skolegangen som en uendelig række af nederlag, har meget bedre af "at komme ud og arbejde".

Men, siger kritikerne, hvor skal de finde arbejde? Det er jo netop manglen på arbejde, der er problemet. Kritikerne er desuden betænkelige ved, at man opgiver tanken om en enhedsskole for alle til og med 16 år. De frygter, at de vanskeligt stillede unge får det endnu sværere.

\section{Politik}

Indenrigsminister Nicolas Sarkozy har spillet en helt særlig rolle i forstads-krisen. Han er den mest forhadte mand i de høje boligblokke og i gårdene mellem dem, for han er "Frankrigs strisser nr. et", og han har kaldt nogle af de unge for "noget pak" - des racailles.

Det kom han til at høre for under efterårets optøjer. Der var mange unge, der sagde, at urolighederne ville holde op, hvis Sarkozy trak ordet "pak" tilbage eller gik af. Men Sarkozy gjorde ingen af delene, tværtimod. Efter at uromagerne havde overhældt en handicappet dame i en bus med benzin og antændt bussen, sagde Sarkozy i en tale til politibetjente: "Når man sætter ild til biler, er man en bølle. Når man hælder en brændbar væske over en handicappet, er man en kriminel".

Når Sarkozy markerer sig så 
stærkt, er det, fordi lov og orden sorterer under ham, og fordi det er hans stil. Men han har også et andet mål for øje, og det er, at en hård linje måske kan hjælpe ham frem til hans karrieres ultimative mål - nemlig at blive Frankrigs næste præsident i 2007. Franskmændene i almindelighed støtter hans linje. En meningsmåling midt under urolighederne viste, at 66 pct. mente han havde håndteret optøjerne rigtigt.

Men Sarkozy har en mægtig fjende i sit eget miljø, og det er præsident Chirac. Han kan ikke døje den lille energiske indenrigsminister, fordi han engang svigtede Chirac under en præsidentvalgkamp. Præsidenten vil derfor gøre alt for, at Sarkozy ikke bliver hans efterfølger, og hans trumfkort er ministerpræsident Dominique de Villepin.

Villepin har tjent Chirac troligt i mange år, og nu prøver præsidenten at få ham profileret som det bedste bud på Frankrigs næste præsident. Det er formentlig forklaringen på, at præsident Chirac selv spillede så tilbagetrukken en rolle under optøjerne. Han overlod scenen til Villepin, som også håndterede krisen med stor værdighed. Selv mange unge i forstæderne er positivt stemt over for ham.

Internt i regeringen har det knaget voldsomt, men de to rivaler Sarkozy og Villepin har været tvunget til at arbejde sammen, dels for at opretholde en samlet front over for uromagerne, men også for at dæm- me op for en højrefløjspolitiker som Jean Marie Le Pen. Han overraskede alle ved det seneste præsidentvalg i 2002 og nåede frem til anden valgrunde, og meningsmålinger viser ikke overraskende, at Le Pen er gået frem under urolighederne.

Han har foreslået, at alle udlændinge fratages offentlig hjælp. Den skal kun gå til "franskmænd", siger han, og argumentet er, at det er "franskmændene", der selv betaler til de offentlige kasser via skatten. Han vil også have det gjort sværere for udlændinge at blive franske statsborgere.

Sarkozy forsøgte at hamle op med Le Pen ved at true med, at alle udlændinge, der har deltaget i urolighederne, skal udvises af landet, også selv om de har en lovlig opholdstilladelse. Han trak senere i land og sagde, at det ikke gælder mindreårige. Af de i alt 3000 anholdte var der 120 udlændinge.

\section{Medierne}

De franske medier - især tv - havde deres problemer med, hvordan de skulle dække urolighederne. Da de havde varet et par dage, begyndte et par af tv-stationerne at pålægge sig selvcensur. De besluttede ikke at oplyse, hvor mange biler, der blev stukket i brand i de forskellige forstæder, for de havde fået en fornemmelse af, at der var gået sport i ildspåsættelser. Hvis de unge i en forstad hørte, at der var brændt flere 
biler i naboforstaden end i deres egen bydel, så kunne man være ret sikker på, at de gik endnu hårdere til den den næste nat. Samme tv-stationer blev også meget tilbageholdne med at vise billeder af de brændende bil, efter at et kamerahold havde været ud for at nogle unge havde sat ild til et par biler bare til ære for tv-holdet.

Selvcensuren har givet anledning til meget debat. De tv-stationer, der valgte ikke at lægge nogen begrænsninger på deres dækning, beskylder de andre for at gå regeringens ærinde, altså at nedtone konflikten.

De unge uromageres forhold til pressen er ambivalent. De vil naturligvis ikke stå frem med navn og adresse eller ansigterne fri for hætter, for så finder politiet dem. Det samme gælder deres familie. Der er også flere tilfælde, hvor de unge har forulempet tv-hold, der prøvede at finde ud af, hvem de var. På den anden side vidste uromagerne også godt, at de var afhængige af især tv. De ville have de brændende biler vist i nyhedsudsendelserne i primetime, for det var den måde, deres protest nåede ud på.

Udenlandsk presse dækkede urolighederne tæt og ikke altid efter franskmændenes smag. Den amerikanske tv-station CNN bragte et kort i deres nyhedsudsendelser, der fik det til at se ud som om hele Paris stod i brand, og at det var farligt for turister at tage til den franske hovedstad. Bortset fra at det kunne koste turistindtægter, så oplever franskmændene det som meget ubehageligt at få det image, at deres land er så plaget af sociale spændinger, at det er for risikabelt at besøge det.

\section{Frihed, lighed, broderskab?}

En britisk avis havde under optøjerne en forside med disse fire ord $\mathrm{i}$ stor opsætning "FRIHED, LIGHED og BRODERSKAB - og VIRKELIGHED?", underforstået, at virkeligheden for beboerne i ghettoforstæderne ikke lever op til de flotte principper fra den franske revolutions tid. Sådan en forside sårer franskmændene, men i al sin forsimplede enkelthed rummer den god del af forklaringen på, hvorfor Frankrig brændte i efteråret 2005.

Connie Pedersen er journalist på TVAvisen og studerer fransk på Københavns Universitet 